\title{
Total Environment for Text Data Mining
}

\section{テキストデータマイニングのための統合環境}

\author{
砂山 渡 \\ 広島市立大学大学院情報科学研究科 \\ Graduate School of Information Sciences, Hiroshima City University \\ sunayama@hiroshima-cu.ac.jp \\ 高間 康史 \\ 首都大学東京システムデザイン学部 \\ Faculty of System Design, Tokyo Metropolitan University \\ ytakamaesd.tmu.ac.jp \\ Danushka
Bollegala
ダヌシカボレガ \\ 東京大学大学院情報理工学系研究科 \\ Graduate School of Information Science and Technology, The University of Tokyo \\ danushkaliba.t.u-tokyo.ac.jp \\ 西原陽子 \\ 東京大学大学院工学系研究科 \\ Graduate School of Engineering, The University of Tokyo \\ nishiharaesys.t.u-tokyo.ac.jp \\ 德永 秀和 \\ 香川高等専門学校 \\ Kagawa National College of Technology \\ tokunaga@t.kagawa-nct.ac.jp \\ $\underset{\text { Muneo Kushima }}{\text { 串䦗夫 }}$ \\ 宮崎大学医学部附属病院医療情報部 \\ Medical Informatics, University of Miyazaki Hospital \\ kushima@fc.miyazaki-u.ac.jp \\ 松下 光範関西大学総合情報学部 \\ Faculty of Informatics, Kansai University \\ materes.kutc.kansai-u.ac.jp
}

keywords: text data mining, total environment, data visualization, graphical user interface

\section{Summary}

In this challenge, we develop and distribute an integrated environment to flexibly combine multiple text mining techniques. Text mining techniques include numerous tasks such as salient sentence extraction, keyword extraction, topic extraction, textual coherence evaluation, multi-document summarization, and text clustering. Although tools that individually perform one or more of the above-mentioned tasks exist, it is difficult to integrate and activate multiple tools for a particular task. We attempt to provide the flexibility to integrate numerous tools that exist in the community in our proposed text mining environment. Users can use a customized version of the proposed text mining environment for their specific tasks, thereby concentrating solely on their creative work.

\section{1.は じめに}

本チャレンジ (TETDM , テトディーエム) では , 複数 のテキストマイニング技術を柔軟に組み合わせて使える 統合環境を構築し，電子テキストを扱う多くのユーザの， 創造的活動を支援するツールの提供を目指す．

テキストマイニングと呼ばれる研究には，「重要文抽出」 「キーワード抽出」「トピック抽出」「テキストの一貫性評 価」「複数文書要約」「テキストクラスタリング」などさ まざまな課題があり，すでに多くの研究成果も世の中で 発表されてきている.しかし，乥れ炎れの技術を利用す るためのシステムやツールは, 各研究者が独自に構築す ることが多く，また論文用の試験的なシステムとなって いたりするため，実際に世の中で使われる技術はごくー 部に限られてしまっている。

また，情報を多角的に分析したいユーザは，複数のテ
キストマイニング技術を用いたいと考える . 各研究者が 配布用のシステムを提供していた場合でも，複数の技術 を併用するためには, 关れらのシステムを各方面から別 個に入手した上で, システム間のデータの受け渡しや結 果の比較のために，手作業でフォーマットを整えたり，新 たなインタフェースを独力で構築する必要が生じる . こ れらのことは，単に手間がかかるというだけでなく，直 感的に試行錯誤を繰り返しながら知見を得る創造活動の 妨げになる .

そこで, 既存また将来の研究成果によるテキストマイ ニング技術を，1つのシステム内のモジュールとして扱 うことができ，ユーザの選択したすべてのモジュールを 連動して動作させられる環境を構築し，乥れを無償ツー ルとして公開することを目指す．これにより，先の問題 点を解決する以下の効果が見込まれる . 
・複数の技術を用いたいユーザの環境か整えられ，ニー ズに応じたモジュールを選択した上で，分析作業に 集中することができる .

・試験的なものを含む多くのシステムやツールが集め られるため，多くの技術の実用化や再利用が見込ま れる。

また，テキストマイニング技術を開発する研究者の利 点として，新しい技術の開発を促進できる次の効果が見 込まれる。

・関連技術を容易に収集することができ，開発技術と 関連技術との比較検討や機能拡張が容易になる．

- 各研究者が研究成果を一つのモジュールとして配付 することを意識できるため，研究の高いモチベーショ ンの維持につながる .

本チャレンジでは最終的に, 複数のテキストマイニン グ技術を併用して分析を行う中で，当たり前の結果だけ ではなく，頻度が低くても価值の高いデータやパターン にも気づくことができ，複数の要因が複雑に絡み合った データの背後に隠れた因果関係を推測して知識創発につ なげられる環境を目指す。

以下本論文では，2 章で TETDM チャレンジの課題と 計画について述へ， 3 章で構築する統合環境の構成につ いて述べる．4 章でTETDM チャレンジの位置づけを明 確にし，5 章で本チャレンジの社会や研究分野への貢献 事例について述べ, 最後に 6 章で本論文を締めくくる．

\section{TETDM チャレンジの課題と 計画}

TETDM では, 複数のテキストマイニング技術を柔軟 に組み合わせて使える統合環境を構築し，作成した環境， および環境内で選択的に使用できるモジュールをダウン ロードできる Web サイト (図 1) を立ち上げることを目指 す．以下で，TETDM でチャレンジする課題と，達成に 向けての計画について述べる.

\section{$2 \cdot 1$ TETDM チャレンジ}

本節では，TETDM で達成したい 3 つのチャレンジと 弚の実現に向けての課題について述べる.

$\S 1$ チャレンジ1：幅広い利用者と開発者の参入

ユーザと開発者の，利用と開発のしきいを可能な限り 下げて，幅広い利用を見込める環境を構筑する．具体的 な数值目標として，100万人のユーザと，1000以上のモ ジュールが集められる環境を想定する . ユーザ数 100 万 という数値の根拠は, 各種商品が 100 万個売れればミリ オンセラーと呼ばれ，ヒット商品として扱われることと， 現在の SNS 上のアプリケーションにおいても , 人気上位 のものは 100 万を超えるユーザ数があることによってい る.またモジュール数 1000 以上としたのは，広くテキ ストデータマイニングに関わる国内の研究者, 開発者が, 平均して一人一つのモジュールを作ることを想定し，幅

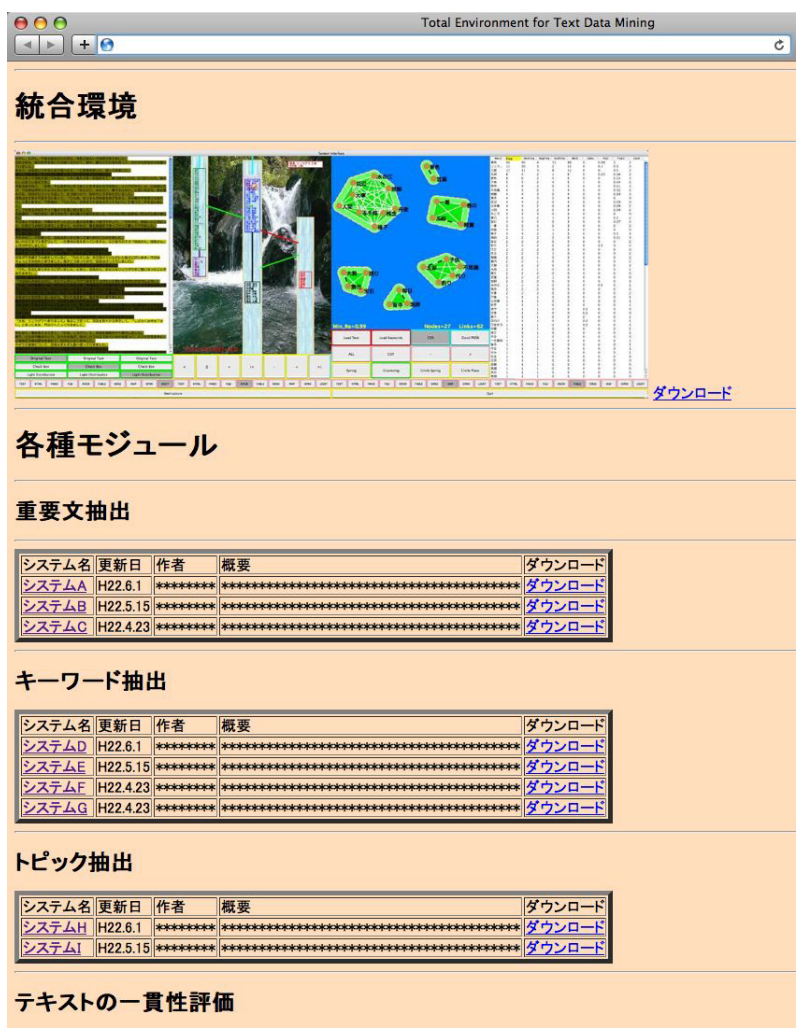

図 1 統合環境とモジュールのダウンロードサイト (イメージ)

広く簡易に開発が可能な場合に達成し得る值として算定 している.

これを達成するための必要条件として, ユーザ側の条 件としては，ユーザか平易に使用できることと，また卑 近なニーズに答えられることなどが挙げられ，開発者側 の条件としては，客観的に効果力確認されていない手法， 試験的な手法など完成度に依存しないモジュールが収集 できることが挙げられる .

これらを踏まえて, チャレンジ1に向けた課題として 以下のものか挙げられる .

a)ユーザの卑近なニーズに応えられること（レポート やメールなど自分の文章や， ロコミ，ブログなど他 人の文章をチェックできる)

b)ユーザの多樣なニーズに応えられること (モジュー ルの種類が豊富で充実している)

c)ユーザが使用する際の手間が少ないこと（簡易で直 感的な操作方法)

d)ユーザの興味を引けること（直感的な面白さを備え， 好印象の噂が広がるようにする)

e)モジュール作成のしきいが低いこと（仕樣の理解と 作成が容易)

f)モジュール作成のための支援環境が整えられること (既存モジュールの拡張や再利用が容易)

g)モジュール公開のしきいが低いこと（バグの不安や メンテの責任 , クオリティの低さに対する懸念など 精神面での障壁の排除) 


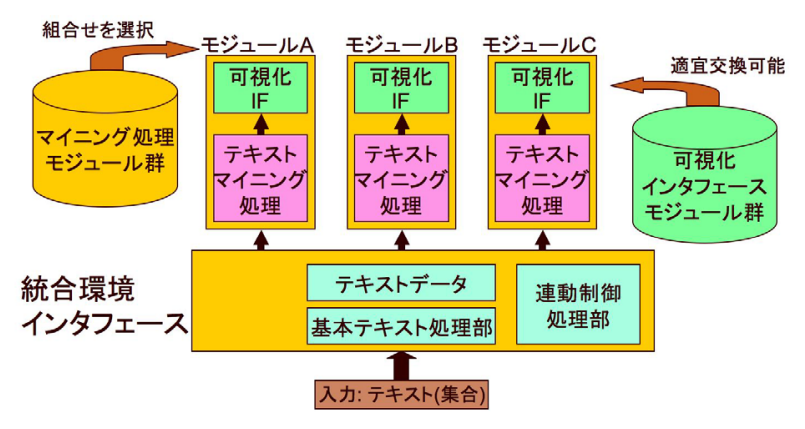

図 2 統合環境構成図

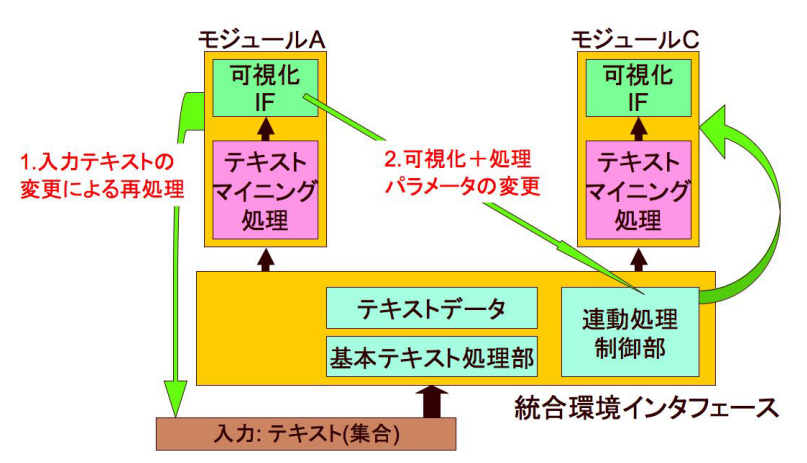

図 3 モジュール間相互インタラクション

h)モジュールの積極的な利用が見込まれること（多く の潜在的なユーザがいること)

$\S 2$ チャレンジ2: モジュール間での相互インタラクショ ンの実現

図 2 の統合環境構成図に示すように, 複数のテキスト マイニング処理モジュールによる出力結果を, 複数の可 視化インタフェースモジュール上に同時に表示して，並 列に並べて比較できるようにする．

特に可視化インタフェースモジュールは, 出カインタ フェースになると同時に, 自モジュールや，他のモジュー ルへの入カインタフェースとしても機能させる (図 3 ) . 単純に, 入力テキストの変更により, 各モジュールで再度 処理を行った結果を表示させる機能（図 3 の 1.) に加え て，ある可視化インタフェースモジュールにおいて「ママウ スによって選択されているデータが，他のモジュールの どこに出力されているかを，自動的に明示」したり，他 のテキストマイニング処理の実行と結果の表示」を相互 に可能にする (図 3 の2.) .

すなわち, チャレンジ 2 に向けた課題として以下のも のが挙げられる .

a)他のモジュールで選択されているデータに対応する データを捉えるために, モジュール間で共通のデー タ構造に基づく連動の仕組みを用意すること

b)他のモジュールを操作するために，他に存在するモ ジュールの情報を共有するためのデータ構造を用意 すること
$\S 3$ チャレンジ3 : 知識創発のための基盤環境の構築

複数のモジュールを併用して, 試行錯誤による結果の 分析を行える環境の中で, 当たり前の結果だけではなく， 頻度が低くても価值の高いデータ, パターンや知識を発 見できる環境を構筑する。

すなわち, チャレンジ3に向けた課題として以下のも のが挙げられる .

a)精度や信頼度に依存しない多樣なテキストマイニン グモジュールが集められること

b)さまざまな角度からの分析が行える多樣な可視化 ンタフェースモジュールが集められること

c)可視化インタフェースモジュールにおいて, 直感的 にデータ間の関係を捉えられ，分析作業に没入でき ること

この a) と b) は主にチャレンジ1の，c) は主にチャレ ンジ 2 の達成が必要条件となり，光れ光れ技術的な側面 もさることながら，ユーザや開発者の精神面においても， 利用や開発をサポートする環境づくりが望まれる．

知識創発の達成のためには, 環境を利用する際のユ一 ザの思考過程と操作内容との関係を詳細に探る必要があ るが , 複数のモジュールを同時に用いて分析を進められ る環境での, 効果的なモジュールの選択方法, 切り替え方 や見せ方，効果的な操作方法など，利用方法に関する多 くの点は明らかになっておらず，弚のすべてを本チャレ ンジで実現できるかは定かではない，しかし，多樣なモ ジュールが集められることを前提として，本環境に限ら ない知識創発を目指すシステム全般において，効果的な 知識創発を実現する際の足がかりや雊形となりえる，基 盤環境を構筑していく.

\section{$2 \cdot 2$ 統合環境の構成要素}

構筑する環境として , 例えば , 二次元ディスプレイ上の 横 640pixel ，縦 900pixel の領域を一つのモジュールのた めの領域として，この領域を縦と横に任意の数だけ並べる ことができるウインドウを作成する . 現在の標準的なディ スプレイであれば，1280×960pixelの解像度を出すこと ができるため，1画面内に2つの領域を表示できる．ま た 30 インチディスプレイ（解像度 $2560 \times 1600$ pixel）で あれば，横に4つの領域 (図 4)を表示することができる

現段階で，モジュールのフォーマットは，盷形クラス を作成した上で，弚れを継承したクラスを作成すること を想定している．また各モジュールは, 图 2 の基本的処 理結果となる, 入力テキストの基本的な情報（テキスト データ) を，共有して利用することを想定している．乥 の他 , オンラインでのリモートサービスによって , 一部 の処理をリモート環境で実行することや，処理の一部を 並列分散化させることは，現在は想定していないが，検 討課題の一つとして考えている.

複数のモジュールを 1 つのウインドウ内で動作させる 環境の構成要素として, 以下のものが挙げられる . 
・統合環境全体のウインドウシステム

・環境が管理するテキストデータのデータ構造

・環境を構成するモジュール群

・環境とモジュールをつなぐインタフェース

・モジュールとモジュールをつなぐ（モジュール間の

連動を可能にする) インタフェース

TETDM では，今後これらに関する仕樣を定めるなど， 次節の計画にもとづいて環境の構築を進める .

\section{$2 \cdot 3$ TETDM チャレンジの計画}

TETDM チャレンジの 5 年間の計画を以下に示す .

- 1 年目 : 統合環境の仕樣の策定

- 2 年目 : モジュールの基本仕樣の策定

・ 3 年目 : モジュール間インタラクションの仕樣の策 定，ダウンロードサイトの立ち上げ

・ 4 年目 : モジュール開発者支援

- 5 年目 : 知識創発に向けた利用者支援

以下で, 各計画の詳細について述べる.

$\S 11$ 年目：統合環境の仕様の策定

图 2 の「統合環境インタフェース」部分の仕樣を策定 する.すなわち, 利用可能なモジュール群の中から，選 択的にモジュールを選んで利用できる枠組み，また，入 カされたテキストデータを保持するためのデータ構造を 定める.データ構造は，多くのモジュールが利用する可 能性の高いデータ (テキスト内の単語の出現情報, 品詞 情報や頻度情報など）についての情報ももつことを想定 しており，図 2 の基本テキスト処理部」において，光 れらのデータを作成する .これは主に，チャレンジ1の c) に関係する .

$\S 22$ 年目: モジュールの基本仕様の策定

モジュール間のインタラクション部分を除いた仕樣を 決定する . 各モジュールの入出力に関わる仕樣，ならび に複数のモジュールを並列に動作させるにあたって，統 合環境とモジュール間でデータの受け渡しを行うための インタフェース (データ構造や関数) を定義する．この 仕樣の策定は，チャレンジ1のa)，b)，e）と主に関わっ ており，ユーザのニーズや開発のしやすさに応じた仕樣 を策定する必要がある。

なお，環境及びモジュールを作成するプログラミング言 語は, 普及率が高く汎用的なオブジェクト指向言語として Java 言語を用いることを想定している．また，Windows， Mac, Linux といった OS の違いや，日本語の文字コード の違い, 英語や数值データへの適用可能性，などを踏ま えた仕樣を検討する .

$\S 33$ 年目: モジュール間インタラクションの仕様の策定

統合環境内で利用される各モジュールは, 弚れ光れが独 立に動作するだけでなく，あるモジュール内での操作が， 他のモジュールにも反映される仕組みを導入する (チャ レンジ 2 ) . 弚のため, 各モジュールが他のモジュール にアクセスするための方法と枠組みを策定する .この仕
組みが実現されることは, チャレンジ1のd)や, チャレ

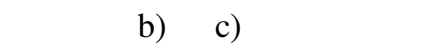

$\S 43$ 年目: ダウンロードサイトの立ち上げ

統合環境と各種モジュールをダウンロードできるサイ 卜を立ち上げる．Web サーバに環境とモジュールのアプ

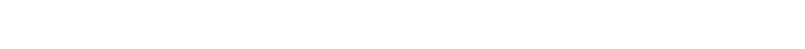
た研究者が, 各自が作成したモジュールをアップロード できる CGI を実装する．これは，チャレンジ1のh)や， チャレンジ3のa)，b)に関わる.

またこのようなサイトが必要な理由として，本環境は 必ずしも万能ではなく, 特に信頼度に依存しないモジュー ルの収集により，日々更新や改訂が行われること，また 目標の 1000 以上の多数のモジュールのすべてを手元に ダウンロードしておいておくことは, 現実的ではないこ とが挙げられる。

$\S 54$ 年目: モジュール開発者支援

モジュール開発者支援として，チャレンジ1のf)，g)， ならびにチャレンジ3のa)，b)に関わる支援の枠組みを 検討する，すなわち，モジュールを容易に作成できるよう に , サンプルモジュールを充実させたり，既存のモジュー ルの再利用を促す環境を構築する . また , モジュールの公 開に当たって，開発者が觉の内容についてのクレームや， 保守の責任などの懸念が発生しないような枠組み, (例え ば匿名の開発者を許すことなど）を検討し，積極的なモ ジュールの公開を促す．モジュールの信頼度を担保する ため，また開発支援として，言語資源として正解データ が利用できるモジュールについては，弚の評価支援を行 うことも検討課題の一つとして考えている.

$\S 65$ 年目: 知識創発に向けた利用者支援

知識創発に向けた利用者支援として，チャレンジ1の

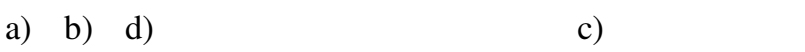
を行う . すなわち，情報推薦の既存技術を応用するなど により，ユーザの多樣なニーズを満たすモジュールをス ムーズに選択できる枠組みの検討 (3·4節でも後述)，な らびに, 効果的な使用例と使用結果などのサンプルを積 極的に公開する。

\section{3. テキストデータ分析のための統合環境}

本章では, テキストデータを分析するための，TETDM チャレンジて構築を目指す統合環境の概要について述べる．

\section{$3 \cdot 1$ 統合環境の利用目的}

テキストデータを分析する局面において，以下のよう な統合環境の利用目的が挙げられる .

1.特定のテキストデータの内容を詳細に理解したい

2.客観的にテキストデータの内容を把握したい

3.より多くの知見をデータから獲得したい

4.創造的活動において新たな行動戦略を創り出したい 


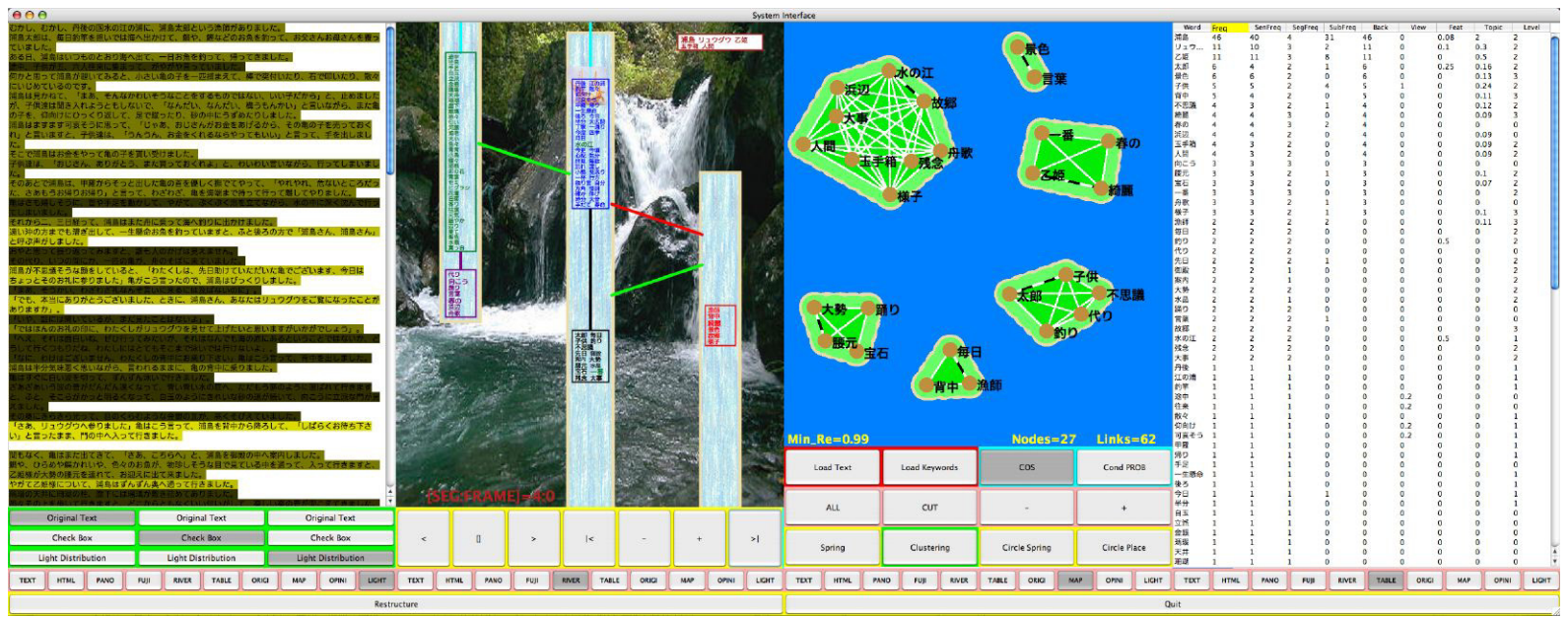

図 4 サンプル環境画面 (解像度 $2560 \times 1000$ )

これらの目的は, テキストマイニングの各システムの 目的としても，挙げられる機会が多い．しかし，単一の システムで達成できることは限られており，これらの目 的を，十分に納得がいくレベルで達成するためには，複 数システムの出力を組み合わせていくことが肝要と考え られる。

\section{$3 \cdot 2$ 統合環境の特徵}

統合環境では，目的に応じたモジュールを選択でき， ユーザ独自の組合せにより処理を行うことができる．ま た , 複数のモジュール間の入出力を連動させる環境によ り，ユーザの操作の手間を省き，データ認識の効率を高 められる.特に各モジュールがもつ視覚化インタフェース を, 出力のためだけではなく, 入力のためのインタフェー スとしても用いられるようにすることで, 各モジュール 上の出力を直感的に操作することによって, 並列に表示 されている他のモジュールの結果も連動して変更される ようにする.

すなわち, 統合環境を用いないで, 複数のシステム間 でデータのやり取りを行う状況に比べると，以下を本環 境の特徵として挙げることができる．

・ューザは目的に応じて，容易に独自のモジュールの 組合せを設定して，使用することができる

・システムの入出力操作の回数を減らすことができる

・複数のシステムからの出力を対応づけて眺められる

・あるシステムの視覚化インタフェース上で, 複数の システムへの入力を, 一度に直感的に与えられる

これら単純で直感的な操作と, データ認識の効率化に より, テキストデータの集中的な分析と, データからの アイデア発生を促す。

\section{$3 \cdot 3$ サンプル環境}

本節では, 試験的に実装したサンプル環境について述 べる*1. モジュール群は主に, 次の 2 つの目的によって 大別される .

1.特定のテキストについて, 詳しい情報を知りたい

2.複数のテキスト間の関係や情報を知りたい

入力となるテキストデータについて，1つのテキスト を入力する際には, 弚の文の区切りを句点で, 段落の区 切りを特定のタグにより認識できる形式で入力する．複 数のテキストを入力する際には, 各テキスト内の文の区 切りが句点で認識できる形式, また複数テキストを $1 つ$ のテキストとして連結し，テキスト間の区切りが特定で きるタグを挿入した上で入力する．

複数テキストを入力する際に1つのテキストとして連 結するのは, ファイル入出力の回数を減らし実行時間の 削減を图るとともに，テキスト間の区切りを，1つのテ キストを入力とした際の段落の区切りと同等に見なすこ とで，1つのテキストを対象としたモジュールにも適用 可能とするための措置となっている .

単一のテキストを入力として，弚のテキストの情報を 表示するサンプル環境上のモジュールを以下に示す．

1)テキスト表示 (兼エディタ)

2)単語の頻度情報の表示

3)キーワード表示

4)要約表示 [相良 07]

5)テキストの一貫性表示 [砂山 08a]

6)意見文表示 [砂山 10]

7)主題関連部分の表示 [西原 09]

複数のテキストを入力とし, 兴のテキスト間の関係を 表示するサンプル環境上のモジュールを以下に示す．

8)2つのテキスト間の差分表示

9)クラスタリング結果表示 [Newman 04]

10)独自性表示 [砂山 08b]

*1 仕樣策定のための実装であるため, 最終的に構築される統合 環境が本節で述べる形式を踏襲するとは限らない。 
図 4 に, パネル (各モジュールの表示領域) を4つ並 ベたサンプル環境の画面を示す (左から順にモジュール 7)，5）,9）,2)）. 各モジュールは $640 \times 900$ pixel の大 きさのパネル上に表示することができ，横に並べるパネ 儿数は, 実行時引数により変えることができる.

ユーザは，使用したいモジュールを，環境下部のボタ ンを押すことで選択できる．モジュール間の連動は一部 でのみ実装されており，たとえば単一のテキストを入力 した際に，3)のキーワード表示モジュールにおいてキー ワードを選択すると，4)で選択されたキーワードを主題 とした要約，5)で選択されたキーワードを主題としたー 貫性表示を行うことができる .

また , 複数テキストとしてレポート集合を入力として 与えたときに，10)による独自性の表示に加えて，3つ

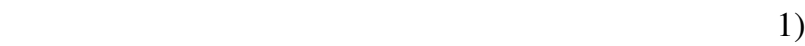
で，弚れらの差分を 8) 上に連動させて表示することがで きる．代わりに10)と6)のモジュールを連動させて , 意 見文が書かれているレポートと炎の独自性を比較するこ ともできる .

\section{4 モジュール選択の指針}

TETDMによって多くのモジュールが集められた際に， どのモジュールを使うべきかという問題の発生が懸念さ れる.より具体的には, 直面している問題に対する適切 なモジュールの組合せが分からない場合と，使用するモ ジュールの出力結果がどの程度信頼できるかわからない という問題が起こると想定される .

前者の問題点に対しては，想定されるタスクに対して， 推奨するモジュールの組合せを提示する機能を環境にもた せることで, 解決できると考えている . 推奨するモジュー ルの決定には，過去に使用したユーザのレビューなどをも とに, タスクと使用したモジュールの組合せに関するデー タを収集することで，タスクごとに推奨されるモジュー ルの組合せデータを作成できると考えている．

後者の問題点に対しては, モジュールのダウンロード サイトにおいて, ユーザによるレビュー機能を設け, ダウ ンロード回数やユーザによる評価結果など，信頼度の指 標になる值を表示する．また各モジュールについて，開 発者側のコメントを載せるとともに，学会，論文誌など での発表があれば，弚の出典の明記を促し，積極的な信 頼性を担保する記述を増すことで，信頼度の評価ができ るようにしていきたいと考えている .

\section{TETDM チャレンジの位置づけ}

本章では, 関連する技術との比較，コミュニティの形 成の視点から TETDM の位置づけを明確にする .

\section{$4 \cdot 1$ 統合型データマイニングソフトウェア}

与えられたデータから知識を得るには, データの前処 理, 本処理, 後処理が必要となる.一般的な原著論文に 記述されるデータマイニング手法は「本処理」の部分に 主眼が置かれているが, 前処理, 後処理もデータマイニ ングにとって重要な役割を持っている [Fayyad 96] . 本節 では, 前処理, 本処理, 後処理も併せて行うべく, 複数 の機能を備えて開発されたデータマイニングソフトを紹 介した上で，本チャレンジの位置づけを行う．

有名な統計処理のフリーのソフトウェアとして R[RProject] がある. R は前処理, 本処理, 後処理の組合せ をユーザ自身が選び，統計計算処理（例えば，線形／非 線形解析, 時系列解析, クラスタリング）と可視化処理 が行え，一つのデータを樣々な手法によってマイニング することが可能となっている．R はデータマイニングに 慣れているユーザにとっては強力なソフトウェアとなる 一方で, データマイニングに不慣れなユーザにとっては 使いづらい可能性がある. TETDM では, 視覚的な入力 インタフェース上で, 直感的に動作可能な環境を構築し， データマイニングに不慣れなユーザにも簡便に利用可能 な環境の構築を目指す。

Weka[Weka] や orange[orange] もフリーのソフトウェ アとして , グラフィカルユーザインタフェースを備えて おり，データマイニングに不慣れなユーザでも利用しや すい．Weka はデータの機械学習を行うことができ，頻 出するデータのパターンを発見することに優れている． TETDM では, 頻出パターンに加えて，希少価値がある データのパターンを発見することも可能な環境を目指し ている。

前処理, 本処理, 後処理の組合せをユーザ自身が選ぶ必 要がないソフトウェアには，ある目的に特化された機能 を備えていることが多く，例えば，顧客の声を分析する目 的のために開発されたソフトウェアとして，DIAMining， Text Mining Studio, TRUE TELLER, Text Mining for Clementine などが挙げられる [DIAMining, Mining Studio, TELLER, Clementine] . これらのソフトウェアはい ずれも商用のソフトウェアとして, 確立された技術をもと にした信頼度の高いマイニング結果を出力する．しかし 信頼度か高い結果は, 既知の一般的知識を多く含み, 発見 的な知識を得ることは難しい．また有償のソフトウェアで あるため，誰もが気軽に用いることはできない，TETDM では, 必ずしも信頼度が高くないが何らかの特徵があり， 応用の可能性を秘めたデータを, 多樣なモジュールの組 合せとデータとのインタラクションを通じて発見できる 環境の構築を目指す．

\section{$4 \cdot 2$ データマイニングの統合環境}

本節では，視覚的なデータマイニング技術の統合環境 として，今までに開発されて来た環境やプロジェクトに ついて述べる。 
VidaMine[Kimani 03] は知識発見プロセスの前処理, 本 処理, 後処理の全てを単一の環境で行うことを目的とし て開発された .しかし対象はテキストではなく，データマ イニングのためのモジュールも多くは集められていない .

辞書や機械翻訳などの言語資源を言語サービスとして 登録し, 共有可能にするインターネット上の多言語サー ビス基盤として, 言語グリッド [言語グリッド]が挙げら れる.さまざまなサービスを登録して相互に利用できる 環境を目指す点は同じであるが, 範囲が言語サービスに 限られており，サービスという側面から主に精度が重視 される．本チャレンジでは, テキストの分析結果をもと にユーザの試行錯誤を促し，新たな発見や発想を促す環 境の構築を目指す点が異なる.

テキストマイニングのための統合的ツールに GATE [GATE] があり，既存のツールの再利用を目指している . 研究の実用化のためのベンチマークテストデータの設定 など, 研究の再利用を意識した作りで, 専属の開発チー ムによるリリースが行われているが, 精度が重視される モジュール構成で, 多樣なモジュールを集められる枠組 みにはなっていない .

ユーザとシステム間のインタラクションを想定した統 合環境に LanguageWare [Language] がある . 入力テキス 卜の言語の推定, 単語の抽出, 品詞の推定, 単語の正規 化, 固有表現抽出などのテキスト分析を行うことができ る .また , UIMA (Unstructured Information Management Architecture) [Ferrucci 04] と呼ばれる基準に基づいてコ ンポーネントを作成しているため，この基準に基づく他 のコンポーネントとの組合せも可能となっている . LanguageWare は, 主にビジネスの現場にいる人をユーザと して想定しており，利用にはテキストマイニングの知識 や経験が求められる．本チャレンジでは，学生や主婦な ど，PC は利用するがテキストマイニングという言葉を知 らないユーザも想定しており，単純かつ直感的に用いら れ，利用価値がある環境の構築を目指す．

種々の言語のデータを, さまざまなモジュールで扱え るようにするためのミドルウェアアーキテクチャとして， Heart of Gold [Heart] がある .コーパスへの自動かつ多 次元のアノテーション, XML ベースでのモジュール同士 の結合などを行える .これは主に, 言語データの中から 共通パターンを見つけ出すことなどを念頭においている が, 本チャレンジでは希少価値のあるパターンを発見で きる環境づくりを目指す．

U-Compare[狩野 08] は処理の実行順序がプログラマブ ルで , 相互依存するコンポーネント (モジュール) を入出 力定義により自動的に組み合わせられる . また , UIMA にも準拠している.U-Compare においても複数コンポー ネントの結果を視覚化して同時に並列表示するが, 本研 究では, 複数の可視化モジュール間でのインタラクショ ンを可能にし, ユーザの集中的な試行錯誤を促せる環境 の構築を目指す.

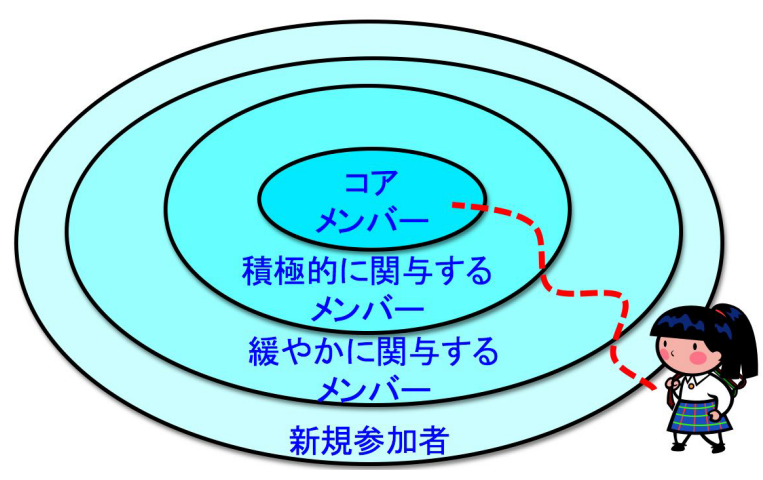

図 5 正統的周辺参加

また入出力やデータの取り扱いに関して, 広く用いら れている UIMA フォーマットの利用に関して，最終的 にどのようなデータフォーマットを利用するかについて， 現在検討中の段階であり， UIMA に準拠させることや， UIMA への適用可能性を残すことも一つの選択肢として 考えている．しかし幅広いモジュールの開発と収集のた めには, 大学等で一通りプログラムを学習した段階の， 開発経験が少ない人でも理解が容易なフォーマットか望 まれるため, 最低限の内容を備えたフォーマットについ て，まずは検討を進めていきたいと考えている．

これら既存のテキストマイニングシステムにおいては， 信頼度の高いモジュールが多く，ヒューリステイツクな手 法 (発見的手法) や思いつきによるアドホックな手法に 基づくモジュールが比較的少ない，客観的な評価を得た システムをモジュールとして収集することはもちろん望 ましいが，モジュール作成のしきいも大きく上がるため, モジュール収集の範囲か狭まったり，新技術の速報性に も欠ける可能性がある．本チャレンジでは，信頼性のし きい值を下げることによって，多樣な技術のモジュール を集められる枠組みを構築し，ユーザの思考を活性化し， 新たな知識の発見を促せる環境づくりを目指す．

また既存のシステムを，本チャレンジの環境で外部処 理として呼び出す事は可能と考えており，光れら既存の システムや, 既存の言語資源等を可能な範囲で統合環境 に組み入れることは検討課題のひとつとして挙げられる .

\section{$4 \cdot 3$ コミュニティの形成}

本節ではコミュニティの形成という立場から TETDM の位置づけや意義を明確化する .

一般に,コミュニティのメンバーは皆が同じ立場で関 わるわけではなく，(1)一人ないし少数のコア・メンバー， (2) 積極的な参画や寄与を行うメンバー，(3) 緩やかに光 のコミュニティに関与するメンバー , と複数の異なる立場 で関わっていく (図 5)．すでに形成されたコミュニティ に新たに参画するメンバーは, (図 5) の周縁部から参画 し,興味が合えば徐々に中心とと，段階を経ながら移行し ていく.これは正統的周辺参加 (Legitimated Peripheral 
Participation) [Lave 91] と呼ばれる参加形態で，このよう な形態が適切に維持されることが，コミュニティの活性 化・発展に繋がる．TETDM が目指すコミュニティ形成も この形態に類すると考えており, ユーザ, 研究者の両方 において , メンバーとしての参画を促していける形態を 模索している．具体的には，学会や研究会において，幅 広くユーザやモジュールの開発者を募集することで, 上 記 (3) に該当するメンバーを集め，TETDM と連動する 研究会を開催することで, 上記 (2) に該当するメンバー が集まれる場所を用意する .

この正統的周辺参加の観点の下で, 複数の研究主体が 協力, 協調しつつ研究の発展を図るための求心力として, 以下の 4 つが挙げられる .

\section{$\S 1$ 情報の提供}

学会誌の解説記事や書籍, あるいはブログや WIKI な どのネット媒体を用いて, 関連する手法や技術の横断的 かつ網羅的な情報ポータルを構築する試みがある．例え ば , テキストマイニング・学習に関するものとしては , 人 工知能学会誌の「私のブックマーク」[長谷川 01]や朱蕗 の杜 Wiki [Wiki] などが光れに当たる .

\section{$\S 2$ 標準インタフェースの策定}

同種の，あるいは類似した目的のシステム間で , 扱える データや知識の共通化を図ることで, 弚れらの比較や検証 を容易にしたり , システムの入出力のプロトコルやフォー マットを共通化することで, 複数のシステムがプリプロセ ス/ポストプロセスという形で連携できるようにしたりす る試みがある . 例えば , 柔軟な形態素解析システム間接続 を行なうためのドライバモデルである MACD [MACD, 松 田 99] などが炎れに当たる．これによって，システム の可搬性や可換性の向上が期待できるため， システム開 発者にとっての動機づけになり得る . 近年では , Yahoo! API[yahoo] など API (Application Program Interface) を 規定することで, 利用者に WEB サービスの機能を部分 的に開放するような試みも増えている.

\section{$\S 3$ テストコレクション・共通課題の提供}

システム間の比較や性能評価のために共通課題や評価 データを提供し，競争的な環境を作る試みがある．特定の テキストコーパスなどを対象とするようなクローズドな 課題であれば, 主催者が人手をかけて事前に作成した正 解データセットや標準回答などを用意し，弚れに基づい て参加者が提出した結果を評価する方法がとられる．例 えば「動向情報の要約と可視化」ワークショップなどが炎 れに当たる .一方，Web や複数年にわたる新聞記事のよ うに, 対象が莫大な, もしくはオープンな場合は, 一部 を抜き出したテストコレクションや課題を提供し，各参 加者がシステムの実行結果を持ち寄って兴の集合を解空 間の全体集合と見做した上で，各々のシステムを評価す る方式 (プーリング方式) や，実行結果を主催者が人手で 評価して順位付けする方式などがとられる．例えば，前 者としては TREC [TREC] などが , 後者としては InfoVis
Contest [Plaisant 07] などが炎れに当たる .

$\S 4$ システム・ツールの提供

直接的な研究成果であるシステムの提供や，データの 整形や整合性チェツクのツールの提供を通じて，他者が 開発したシステムとの比較を可能にしたり，乥れらのシ ステムやツールを利用，拡張して別のシステムを開発で きるようにする試みがある . 例えば , 近未来チャレンジ 「情報編纂の基盤技術」における可視化プラットフォーム [松下 09]などが光れに当たる．

\section{$4 \cdot 4$ コミュニティ形成への道筋}

研究主体のコミュニティには, 類似した研究テーマの実 践を行う主体か情報交換を目的として集う形態 (Community of Practice , 以下 CoP)[Lave 91] と，ある目的の下で， 異なる専門性や関心を持った主体が連携や協同を目的と して集う形態 (Community of Interests , 以下 CoI)[Arias 00]の, 二つの形態が考えられる . 特に後者は, 対象とす る課題の複杂隹化や分野横断化に伴い, 近年樣々なかたちで の協同が模索されている. TETDM は , この二つのコミュ ニティの側面を併せ持つプロジェクトとして位置づけら れる .すなわち, $4 \cdot 3 \cdot 1$ 節のような情報提供のためのポー タルをベースとして，多くのテキストマイニング技術を 統一的に連動させて扱えるようにすることで, $4 \cdot 3 \cdot 4$ 節 に相当する環境を提供する，いわば「ワンストップサー ビス」としての場の実現を目指している．光のため，こ の場は, CoP と CoI が邂逅する場ともなり得る .

すなわち，テキストマイニングツールを開発する人々 (Community of Practice) からすれば, 各々が作成した ツールの比較競争の場とみることができ，光れらを利用 する人々 (Community of Interests) にとっては , 提供され たマイニングツールを利用して自らの問題の解決や解消 に役立てられる場となる .

CoPの立場からすれば , 自らのシステムを利用するユ一 ザを確保できる点や, 樣々な観点からの競争や連携か期 待できる点が，システム提供の動機づけとなる．また， CoI の立場からすれば, ニーズに応じた技術の選択や比 較が容易なため本来の興味である課題 (分析作業) に集 中できる点が , 利用の動機づけになる .

これらに加え, コミュニティに参画するための最初のし きいを可能な限り下げることで，より大きなコミュニティ の形成を目指す．すなわち，TETDM が提供する環境に ついて , CoP の開発者の立場であれば何らかのモジュー ルを作成することが, CoI のユーザの立場であれば本環 境を用いてみることが, コミュニティ参画へきっかけに なると考えられる．したがって，開発のためのモジュー ルの仕樣を厳しく定めないとともに, モジュールの畋形 やサンプルを提供することで「自分にも作れとう」と思 える仕樣, またユーザとして使用する際の手間，および 使用の説明を最小限に留められ, 直感的に「使いやす光 う」と思える, また产の出力が魅力的で「面白光う」と 
思える見た目を用意する．

\section{5. 社会の発展や研究促進に向けた応用事例}

本章では，TETDM チャレンジによる環境が，社会や 研究開発の場面で用いられる応用事例について述べる .

\section{$5 \cdot 1$ 社会や研究開発における卑近な使用例}

現在の世の中は，多くの情報を獲得するとともに，光 れらをいかに分析して次の行動につなげていくかが問わ れている．弚の際に情報を多角的に分析できるツールは 必須と考えられる.コンピュータを使っていて電子テキ ストを扱わない人はおらず，簡便で実用的な環境の上で， 多角的にテキストを分析できるツールへのニーズと期待 は高いと考えられる．多くのユーザの利用が見込まれる 卑近な使用例としては, メールの作成支援として, 自分 の作成したメールの誤字や脱字, 敬語のチェック, 読んだ 人が受ける感情の推定結果などを表示することや, Web ページ検索の結果のテキスト集合や，興味あるブログや つぶやき [twitter]のテキスト集合から，キーワードや関 連語情報, 分類結果と各分類の要約を提供することなど による，情報へのアクセス支援と，新たな興味への発想 の手がかりを提供することが考えられる .

また，研究開発者が作成したシステムの評価を行う際 には，類似システムとの比較が必要な場合が多い，新し い技術か研究論文として発表されても, 弚れが実際に活 用されるためには，論文の著者からツールをもらうか， 独力で実装する必要がある.1つの共通の環境が存在し て，谷のモジュールとしてダウンロードが可能になれば， 既存研究との比較も容易になると考えられる.

\section{$5 \cdot 2$ 大局視と局所視の融合による探索的データ分析}

動向情報の分析など探索的データ分析が必要な場面で は, データの全体像 (大局視, overview) と各データの 詳細 (局所視, detail) の両方を提示することが重要とい うコンセプトがある. しかし多くの可視化モジュールに おいては，この大局視あるいは局所視のどちらかに適し ている (特化している) . 動向情報には, 時間的動向情報

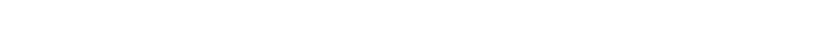
表現が異なる (例えば, 時間的動向は折れ線グラフ, 空 間的動向は地图など）ので, 光れ光れに適したモジュー ルを複数用意する必要がある.また，時間的／空間的両 方の性質を持つ動向情報の存在や，探索的分析において は時間的, 空間的両面から分析を進める必要があるため， モジュール間の連携が不可欠となる．

ユーザの観点からの利点として , 大局視，局所視（あ るいは空間的動向，時空間的動向）弚れ光れについて多 樣な可視化技術が存在するため, 弚の中からユーザが好 むものを選択して分析環境を構筑できることが挙げられ る.また開発者の観点からの利点として，例えば，大局
視用の新しい可視化技術を開発し，他の大局的可視化手 法と比較したい場合, 局所視部分などの他の要素につい ては条件を揃えて実験をしたい，というケースはよくあ る. 弚のような要望を, TETDM の環境では容易に叶え ることができる .

\section{$5 \cdot 3$ 電子カルテのテキストマイニング}

病院に蓄積されているデータのほとんどは構造化され ていないテキストデータであると言われており，テキス トデータから興味深く重要なパターンを抽出し, 光の分 析結果を視覚化するテキストマイニングが注目を集めて いる、特にデータ量か膨大になると，データ自体を整理 することさえ困難な現状がある．乥こで，このような大 量のデータから医療行為に活用できる知識を獲得する際 に，複数のテキストマイニング技術を連動させる環境が 活用できる。

例えば，多くの電子カルテのテキストデータ集合を米 の内容に応じてクラスタリングする際に,「テキストデー タ集合からキーワードを抽出するモジュール」と連動さ せて「クラスタリングモジュール」の分類基準を決定す ることで, より柔軟なクラスタリング結果を表示できる また, クラスタを選択した際には, 各クラスタの代表的 なカルテの要約を表示するための「テキスト自動要約モ ジュール」や，ピックアップしたクラスタ内のカルテ間の 関係を示すために「ネットワーク可視化モジュール」を 利用することなどにより，隠れた関係性や意味を見つけ 出すことができる．

蓄積された電子カルテのテキストデータ (看護記録 ・ 経過記録) をテキストマイニングにより解析し活用すれ ば，医師，看護師等の教育や評価に活用できるほか，べ テランの医師，看護師でなくても適正な記録がなされて いるかどうかの判断材料とすることで，医師，看護師で なくても診療情報管理士による質的監査が可能になると 考えられる [Kushima 10] . 他にも，患者の疾患の予後 · 予後因子・治療成績・医療技術の安全性等を評価する臨 床研究データを集積し, 臨床研究のコスト削減・効率化・ 品質向上に繋げるなど，テキストマイニング技術の応用 の幅は広く，これら多樣な目的のために，個々にシステ ムを構築することは現実的ではない .

\section{4 開発済みモジュールの適用範囲の拡大}

研究者の立場の応用として, 既存ツールの新しいドメ インへの適用可能性 [Daume 06] を探ることへの応用が 考えられる、例えば言語処理の分野で「言語解析ツール (形態素解析器, 固有名詞抽出器, 係り受け解析器, 評判 分析器など)」を弚れらを学習させたドメイン (例えば 新聞記事，Wall Street Journal コーパスなど）と全く異な るドメイン (例えばブログ, twitter など) で適用する場 合，どのようなところで問題が起こるか，どのようなエ ラーを引き起こすか, 乥してどうすれば新しいドメイン 
へ適応できるか (domain adaptation) という研究が盛んに 行われている．今後更に多樣なドメインか増えていくと 予想されるため，このようなニーズは今後増していくと 考えられる

そのような場合「ドメイン適用性を調べたいツール（モ ジュールX)」と「2つのテキストを比較して，共通点 や相違点を列挙するモジュール」および「(列挙された) データを分類して視覚的にクラスタリングするモジュー ル」と連動させることで，ある新しいドメインに対する モジュールXによる処理結果（テキストA）と，他に用 意した理想的な処理結果 (テキスト B) とを比較して, 視 覚的に分析を行うことが容易になる．また，他に競合し 弚うなツールによる結果を並へてて見たり，類似ツールと の結果の比較分析も可能になる .

\section{6. 結論}

TETDM チャレンジでは, 複数のテキストマイニング 技術を柔軟に組み合わせて使える環境を構築し，光れら を広く提供することを目指している．本環境により，複 数の技術を用いたいユーザの環境か整えられ，ニーズに 応じたモジュールを選択した上で，集中的して作業を行 うことができるようになると期待できる .

個別のテキストマイニング技術を開発する際に，他の 技術との連携を意識して視野を広げつつ，本環境に統合 することができれば，多くの研究か認知，実用化される ようになり，ユーザの情報の多角的な分析に基づく創造 的開発, 研究, 経営戦略の立案などが支援されると期待 できる .

TETDM チャレンジが目指す環境は，より多くの人に 認知されて初めて成立するため，多くの方々の積極的な こ助言とご助力を賜りたいと考えている.多くの人々が 集団となったときのエネルギーがあれば，テキストマイ ニングの技術開発は飛躍的に進むと期待でき，またテキ ストマイニング分野での成功か認知されれば，他の技術 開発分野でも同樣の動きが現れ，世の中のさまざまな技 術の格段の進歩が見込まれる.

\section{謝 辞}

本論文の完成に当たり，査読者の方々から，大変有益 なこ助言を頂きました・ここに記して感謝致します。

\section{$\diamond$ 参 考 文 献 $\diamond$}

[Arias 00] E. Arias, H. Eden, G. Fischer, A. Gorman, and E. Scharff: Transcending the Individual Human Mind: Creating Shared Understanding through Collaborative Design, ACM Trans. on ComputerHuman Interaction, Vol.7 No.1, pp.84 - 113, (2000).

[Clementine] Text Mining for Clementine (http://www.spss.co.jp/software/modeler_ta/)

[Daume 06] Hal Daume III and Daniel Marcu: Domain Adaptation for Statistical Classifiers, Journal of Machine Learning Research, Vol
26, pp.101 - 126, (2006).

[DIAMining] DIAMining

(http://www.mdis.co.jp/products/diamining/)

[Fayyad 96] Usama M. Fayyad, Gregory Piatetsky-Shapiro, Padhraic Smyth: Knowledge Discovery and Data Mining: Towards a Unifying Framework, KDD, pp.82 - 88, (1996).

[GATE] GATE (http://gate.ac.uk/)

[言語グリッド] 言語グリッド (http://langrid.nict.go.jp/jp/)

[長谷川 01] 長谷川隆明 : 私のブックマーク「テキストマイニン グ」, 人工知能学会誌, Vol.16. No.6, p.893, (2001).

[Heart] Heart of Gold (http://heartofgold.dfki.de/)

[狩野 08] 狩野芳伸, 辻井潤一：UIMA を基盤とする相互運用性の 向上と自動組み合わせ比較一国際共同プロジェクトU-Compare , 情報処理学会自然言語処理研究会報告, Vol.2008, No.67, pp. 37 42, (2008).

[Kimani 03] S. Kimani, S. Lodi, T. Catarci, G. Santucci and C. Sartori: VidaMine:A Visual Data Mining Environment, Journal of Visual Languages and Computing, Vol.15, No.1, pp.37 - 67, (2004).

[Kushima 10] M. Kushima, K. Araki, M. Suzuki, S. Araki, and T. Nikama: Graphic Visualization of the Co-occurrence Analysis Network of Lung Cancer in-patient nursing record, proc. of The International Conference on Information Science and Applications(ICISA 2010), pp.686-693, (2010).

[Language] LanguageWare (http://www.ibm.com/software/ jstart/languageware)

[Lave 91] J. Lave and E. Wenger: Situated Learning: Legitimate Peripheral Participation, Cambridge Univ. Press, (1991).

[MACD] MACD (http://chasen.aist-nara.ac.jp/macd/)

[松田 99] 松田寛: 形態素解析システム相互接続ドライバモデル MACD の設計，「言語資源の共有と再利用」シンポジウム論文集, (1999).

[松下 09] 松下光範, 加藤恒昭 : 情報編纂研究促進のための試み, 人工知能学会誌, Vol.24, No.2, pp. 272 - 283, (2009).

[Mining Studio] Text Mining Studio (http://www.msi.co.jp/tmstudio/)

[Newman 04] Newman, M.E.J.: Fast Algorithm for Detecting Community Structure in Networks, Physical Review E 69, 066113,pp. 1 $-5,(2004)$.

[西原 09] 西原陽子, 佐藤圭太, 砂山渡 : 光と影を用いたテキス 卜のテーマ関連度の可視化, 人工知能学会論文誌, Vol.24, No.6, pp. $480-488$, (2009).

[orange] orange (http://www.ailab.si/orange/)

[Plaisant 07] C. Plaisant, J. D. Fekete, and G. Grinstein: Promoting Insight-Based Evaluation of Visualizations: From Contest to Benchmark Repository, IEEE Trans. on Visualization and Computer Graphics, Vol. 14, No.1, pp.120 - 134, (2008).

[R-Project] R-Project (http://www.r-project.org/)

[相良 07] 相良直樹, 砂山渡, 谷内田正彦：サブトピックを考慮 した重要文抽出による報知的要約生成, 電子情報通信学会論文 誌, Vol.J90-D, No.2, pp.427-440, (2007).

[砂山 08a] 砂山渡: テキストの話の流れを視覚化するインタフェー ス, 第 22 回人工知能学会全国大会, 1B1-1, (2008).

[砂山 08b] 砂山渡, 川口俊明 : 内容の独自性の視覚化によるレ ポートの独自性評価支援システム, 人工知能学会論文誌, Vol.23, No.6, pp.392-401, (2008).

[砂山 10] 砂山渡, 川口俊明, 田村幸寛 : レポートの課題との関 連度と意見文抽出による情報量評価支援, 電子情報通信学会論文 誌, Vol.J93-D, No.10, pp.2032-2041, (2010).

[TELLER] TRUE TELLER (http://www.trueteller.net/)

[TREC] TREC (http://trec.nist.gov/)

[twitter] twitter (http://twitter.com/)

[Ferrucci 04] Ferrucci, D. and Lally, A. : UIMA: an architectural approach to unstructured information processing in the corporate research environment, Natural Language Engineering, Vol.10, No.3-4, pp.327-348, (2004).

[Weka] Weka (http://www.cs.waikato.ac.nz/ml/weka/)

[Wiki] 朱鷺の杜 Wiki(http://ibisforest.org/)

[yahoo] Yahoo! API (http://developer.yahoo.co.jp/)

〔担当委員：阿部 明典〕 

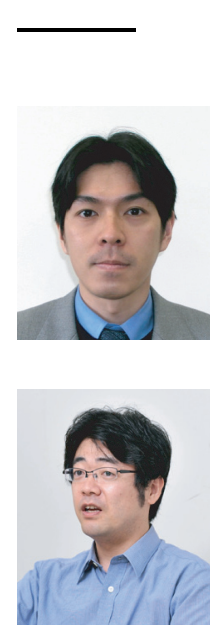

\section{砂山 渡(正会員)}

1995 年大阪大学基礎工学部制御工学科卒業. 1997 年同大 大学院博士前期課程修了.1999 年同大大学院博士後期課 程中退. 同年同大学院助手, 2003 年広島市立大学助教授, 2007 年同准教授，現在に至る.博士 (工学) . 人間の創造 活動を支援する研究に興味を持つ、電子情報通信学会, 言 語処理学会, IEEE, 各会員 .

\section{高間 康史(正会員)}

1994 年東京大学工学部電子工学科卒業. 1999 年同大学院 博士課程修了. 1999-2002 東京工業大学大学院総合理工学 研究科助手, 2002-2005 東京都立科学技術大学助教授, 2005 年より首都大学東京システムデザイン学部准教授。博士 (工 学). Web Intelligence や情報可視化, 知的インタフェース の研究に従事. 主要著書は「インテリジェントネットワーク システム入門」(コロナ社). IEEE, 日本知能情報ファジィ 学会, 情報処理学会, 電子情報通信学会各会員.

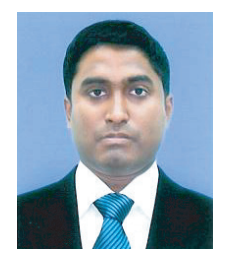

\section{Danushka Bollegala}

2005 年東京大学工学部電子情報工学科卒業, 2007 年同大 学院情報理工学系研究科修士課程修了, 2009 年同研究科 博士課程修了 (短縮修了). 博士 (情報理工学). 現在, 同 研究科助教.

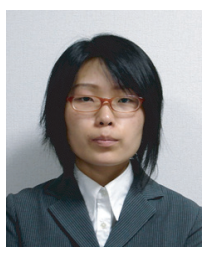

\section{西原 陽子(正会員)}

2003 年大阪大学基礎工学部卒業. 2005 年同大大学院基礎 工学研究科博士前期課程修了. 2007 年同研究科博士後期 課程修了. 博士 (工学) . 日本学術振興会特別研究員を経 て, 2008 年東京大学大学院工学系研究科助教, 2009 年同 講師, 現在に至る。コミュニケーション支援, サービスデ ザインに興味を持つ、情報処理学会, 医療情報学会, 機械 学会, 各会員.

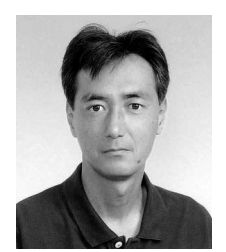

\section{徳永 秀和(正会員)}

1986 年東京工業大学大学院総合理工学研究科修士課程修 了. 同年新日本製鐵（株）勤務. 1993 年高松工業高等専 門学校講師 . 2005 年同校助教授 , 2007 年同准教授 , 2009 香川高等専門学校准教授, 現在に至る。博士 (工学) . Web からの知識獲得, 知識共有の研究に興味を持つ。情報処理 学会, 日本知能情報ファジィ学会, 各会員.

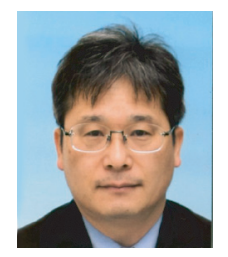

串間 宗夫(正会員)

1987 年宮崎大学大学院工学研究科修士課程修了. 2003 年 同大大学院工学研究科博士後期課程修了. 2008 年同大大 学院医学系研究科博士課程医学尃攻入学, 現在に至る. 博 士 (工学). 地方公務員。医学系では, 癌治療, 診療情報, 電子カルテ, 地域医療連携，工学系では, MOS アナログ 集積回路, 多值論理回路, 教育工学, に興味をもつ. 日本 医療情報学会, 電子情報通信学会, 多値論理研究会, バイ オメディカル・ファジィ・システム学会, 各会員 .

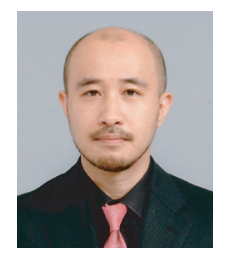

\section{松下 光範 (正会員)}

1995 年大阪大学大学院基礎工学研究科物理系専攻制御工学 分野博士前期課程修了. 同年日本電信電話 (株) 入社. 2008 年 関西大学総合情報学部准教授, 2010 年 同教授，現在に 至る . 自然言語理解, 情報可視化, ヒューマンコンピュー タインタラクションに関する研究に従事.情報処理学会, 日本知能情報ファジイ学会, 日本バーチャルリアリテイ学 会, ACM 各会員. 博士 (工学). 